\title{
Modern development strategies of the Russian education in the conditions of the information society
}

\author{
Mikhail V. Boguslavskii ${ }^{1, *}$ and Igor D. Lelchitskii ${ }^{2}$ \\ ${ }^{1}$ ISED RAE, Laboratory of History of Pedagogy and Education, 105062, Moscow, Russia \\ ${ }^{2} \mathrm{TSU}$, Institute of Pedagogical Education, Tver, Russia
}

\begin{abstract}
The article presents current development strategies of the Russian education in the conditions of information society. Western-liberal and traditional-conservative strategies of modern Russian education development are substantively presented. The ways of harmonization of these strategies in the area of national education in the information age are characterized. Approaches to the implementation of historical and pedagogical expertise of modern development strategies of the Russian education are proved.
\end{abstract}

Throughout its historical development the domestic education has repeatedly been subjected to reforms and modernizations, that changed its direction, content, structure in varying degrees and in different aspects. This process immanently involves a historical analysis of development and implementation process of the Russian education modernization strategies. In this context great significance is devoted to the study, theoretical understanding and generalization of the historical experience of the development and implementation of modernization strategies of domestic education during the XVIII-XIX centuries, but especially in the XXbeginning of the XXI century [1].

The status of education modernization strategy is the highest level of analysis of education reform processes, the general program of its development, that determines the target and value priorities, methods of recruitment and the allocation of resources, and a series of steps to achieve the goals, and, to a large extent, to comply with the established state of internal and external environment.

Education Modernization Strategy of the Russian Federation is an officially recognized system of strategic priorities, objectives and measures in the field of education, stating the condition of the Russian education system and defining the main directions of education system development for the medium and long perspective.

The purpose of the modern strategy of the Russian education development in the information society is to generate the highest possible sustainable competitive advantage of the Russian education in the modern world, not by tactical maneuvering, but through the adoption of a common long-term perspective. Wherein, these strategic decisions should be aimed at providing a significant and lasting impact on the development of education. Strategic decisions taken, they cannot be changed during a certain historical period [2].
All these difficult realities are embodied in a number of documents of strategic and predictive nature, for example, «Strategy-2020 concept of long-term socioeconomic development of Russia until 2020» (2011), where there is a substantial section devoted to the justification of the strategic vision of the processes and results of the Russian education system modernization.

The same strategic character for the modernization of Russian education have previously adopted documents such as the «Russian Innovation Development Strategy for the Period Until 2020»(2011), "Russian National Security Strategy until 2020»(2009), and «The Concept of Long-Term Social and Economic Development of the Russian Federation for the Period Until 2020» (2008), which is the first version of the «Strategy 2020».

Directly in the sphere of education at the current stage the following Federal Laws have strategic nature: «On Education in the Russian Federation» (2012), which has entered into force since the $1^{\text {st }}$ of September, 2013; and two programs - «Program of Education Development Until 2020» (2012), and the Order No.2620-r of Prime Minister of the RF Dmitry Medvedev "Changes in the Social Sectors, Directed on the Education and Science Improvement» (2012), known as the «road map», state program of the Russian Federation «Development of Education» for 2013-2020 years (2012), the Plan of activities of the Russian Federation Ministry of education and science for 2013-2018 years (2012), Concept of the federal target program of education development for 2016-2020 years (2014).

Moreover, strategic character in the sphere of education has the following documents: Message from President Vladimir Putin to the Federal Assembly (20122015); State program «Strategy of Development of Education in the Russian Federation for the Period Until 2025» (2015); State program «Patriotic Education of Citizens of the Russian Federation for 2016-2020 years»

\footnotetext{
Corresponding author: hist2001@mail.ru
} 
(2015), and the proceedings of the meeting of the State Council on the improvement of the educational system in the Russian Federation (2015) [3].

The system analysis of these documents eloquently gives evidence that the processes of developing of a strategic vision of the perspectives of education development are extremely relevant nowadays. Implementation of modernization of the Russian education, built on these principles, ensuring effective interaction between the state and society in the development of education modernization strategy, requires a comprehensive scientific study and a strategic forecast of the results of planned strategic changes in the modern information society.

At the same time the epistemological and analytical tools, contained in these strategic documents, and also proposed approaches to the development of the Russian education modernization strategy is a template for the formation of theoretical and methodological basis in this direction for the retrospective studies implementation, conducting their historical and pedagogical expertise.

Results of historical and pedagogical expertise must always be taken into account when making strategic decisions in the field of education; these decisions must be highlighted by historicism [4].

In this regard, the task is actualized: to establish the documents at each historical stage, that can be interpreted as strategic ones. Thus it is possible to judge the implementation of multiple, successive strategies for the development of the Russian education.

Theoretical and methodological basis of historical and pedagogical analysis of the Russian education modernization strategy involves the synthesis of general scientific principles and approaches, as well as of special scientific methods of cognition.

The methodological basis of historical and pedagogical analysis of the Russian education modernization strategy is considered to be a combination of two basic approaches [5]:

- theory of political modernization - G. Almond, D. Apter, R. Aron, D. Bell, S. Black, L. Binder, T. Veblen, S. Verba, R. Inglehart, D. Coleman, L. Pai, T. Parsons, D. Lapalambara, M. Levy, W. Rostow, A. Touraine, J. Habermas, S. Huntington, W. Zapf, S. Eisenstadt, D. Epter;

- concept of strategic management (I. Ansoff).

In this historical and pedagogical analysis of the Russian education modernization strategies can objectively be implemented only within the framework of interdisciplinary research $[6 ; 7]$. It is based on research carried out by philosophers and political scientists, sociologists and historians:

- in the sphere of modernization processes;

- in the field of organization and management of modern management theories;

- in a cluster of modern educational policy;

- in the field of historical and educational research specifically dedicated to the study of reform and modernization processes in the Russian education.

The use of general scientific principles of dialectics and historicism makes it possible to consider the process of modernization of education in the context of its development and spatial-temporal determination. Systemic and structural-functional methods of analysis of changes in the sphere of education are used to assess the interdependence of the positive achievements in the field of modernization of education on the development of relevant public institutions in the information society.

Among the applied methods a certain value is given to event-analysis. Thanks to this analysis by means of discussions about the ways how to reform education, some tendencies are revealed, that allow evaluating the proposed direction of modernization processes in the information society [8].

Carrying out the historical and pedagogical expertise it is necessary to consider that the peculiarity and complexity of the modern educational situation in the Russian Federation in the conditions of information society is the simultaneous existence and realization of two positive educational strategies, what is more they are built on various ideological and pedagogical grounds.

Let's have a detailed look at these strategies.

1. Strategy based on western, liberal, personcentered, and innovative values defines externally the processes occurring in the Russian general education (Unified State Exams, Federal State Educational Standards) in the information society and especially in higher education (implementation of the Bologna process provisions).

Upon this target-value basis the key strategic documents of the Russian Federation Government in the sphere of Education and the Ministry of Education and Science of the Russian Federation until 2013 year are prepared.

A number of strategic principles, on which the modernization of education in the information society must be carried out, are formed in these documents.

In the aspect of analysis of the target-value basis of this western-liberal policy, we note that those who can be related to liberals, have always seen their goal in progressive accelerated development of the national education as a powerful factor of modernization of the entire Russian society, especially in today's information society.

In this regard, they promoted the ideals of the education, being independent of the caste, built on universal values, i. e. in many respects they took over the Western European model of education. In the contents of education the accent was made on the «real» knowledge that was considered as modern - exact and natural sciences, the Russian language and new modern languages. Regarding educative ideal, such ideals as people's patriotism, and individual freedom took a very important place [9].

However, it appears that in the present situation the strategy based on western, liberal person-centered and innovative values has been exhausted ideologically, and it will not determine any more the prospects for education policy in the modern information society.

In determining the prospects of the Russian education development, western processes are generally being evaluated carefully and critically. This is due to the fact that the ongoing reform of the Russian education of the late XX - the beginning of XXI century, based on 
western-liberal strategy, were clearly pronounced as «catching up» modernization that happened in the sphere of education under strong influence of western countries, that were ahead of Russia in their development.

This process determined borrowing of pedagogical technologies, adaptation of national education to samples arising under other conditions, and on the one hand it made a certain progress in education, but on the other hand it gave rise to significant negative consequences.

According to historical analysis, in the modern information society «catching-up modernizations» are generally inefficient in intellectual spheres (including education). Being organized from the outside, they assimilated other countries patterns mostly in a passive way, but they did not elaborate their own priorities, did not change the terms, and did not form new national goals.

These conclusions are confirmed by the fact that during 2014-15 years in line with western-liberal strategy we don't observe developmental trends; we can only see the adjustment of certain provisions, and even a certain dismantling of some of them. This is especially true in the current situation around the federal educational standards for general education.

2. Currently one can notice a complex process of developing a new strategy for the development of the Russian education on the basis of a potential combination of its traditional strengths, and at the same time ensuring the Russian education the competitiveness in the modern world in the information society.

This situation is due to the fact that after the election Vladimir Putin the President of the Russian Federation, starting with the presidential decrees from the $7^{\text {th }}$ of May, 2012, and during the subsequent period, explicitly and increasingly, the senior management of the country began to form the arrangement to develop and implement the Education Development Strategy, built on the Russian national-patriotic and traditionally conservative basis, socially oriented public values and retro innovative discourse [10].

As we can see, the basic values underlying simultaneously realizing strategies of the Russian education strategies are opposite. In this context, social relations, cultural connections, and religious attitudes, being traditional for the Russian society have the principle importance for the successful modernization. It is important to note that the modernization is carried out mainly on the basis of traditional Russian roots, where there is our own vision of prospects of national education development, unlike the reforms undertaken purely on the Western model.

This discourse, to a large extent, serves as an alternative to liberal-western model that ideologically exhausted itself. In fact due to the lack of adaptive mechanisms of Western culture to the realities of the domestic education, this model meets the growing criticism and the increasing resistance of the pedagogical community.

In this respect, the success of social and cultural modernization of national education in today's information society depends on the traditional for the
Russian society social relations, cultural connections, and religious attitudes.

Undoubtedly the design of a new strategy for the development of national education on a traditionally conservative basis in today's information society objectively requires a comprehensive historical and pedagogical expertise of the process of elaboration and implementation of such modernization strategies of education in the past. In this regard, a special interest is put to the reflection of ideas of Russian pedagogical conservatism representatives, produced in previous historical cycles, the priority research of the genesis of traditional-conservative paradigm in domestic pedagogics in the XIX-XXI centuries on the whole.

Therefore, historical and pedagogical expertise of the retrospective experience of formation and practical implementation of educational policy based on the traditional-conservative basis can improve the effectiveness of joint efforts of the state, pedagogy, teaching community and public institutions to develop and implement a new harmonious socio-cultural modernization of Russian education [4].

To do this, first of all, there must be a full recognition as a progressive conservative dominance in the design of strategy of the Russian education development and implementation of its historical and pedagogical expertise. On this axiological basis in future it is possible to form a new strategy of the Russian education development; this strategy is built on the priority of the traditional values of the Russian civilization.

In terms of social change conservatism is manifested in the restoration of lost positions, in recognition the value of past ideals. At the same time the very existence of traditional institutions and values should be considered as a factor contributing to the modernization of education.

The projection on the modern development of Russian education, carried out during the second half of 2012 2015 years the returnable modernization, embodied in the following directions of state policy in the field of education:

- a significant increase of the legislative, normative and regulatory role of the state;

- regulation of professional activities and conduct of participants of the educational process;

- narrowing of the space variability;

- complexity of the qualification procedures;

- greater emphasis on the fact that the behavior of all subjects of educational activity must conform to social norms.

As it is known, it is typical for conservatives to see the «golden age» of maintaining their ideas in the historical past. In today's reality, some pedagogical conservatives appeal to the pre-revolutionary tradition, others stick to the Soviet one. But it is more promising to create of some new synthesis of new conservative values of the Russian education, including the most valuable things, and something taken from the whole historical and pedagogical experience [4].

Undoubtedly, the "Golden Age» of currently producing the neo-conservative paradigm, mainly refers to the historical time of the Soviet education system of 
the second half of the 1970 - early 1980 years. During 2013-2015 years retro innovations are expressed in a consistent return (or motion for the return) of most productive forms and methods of pedagogical activity of the Soviet education system of that period into the Russian education.

The following things take place:

- implementation of a systematic and purposeful extracurricular educational activities of civil-patriotic (the Government of the Russian Federation has developed and adopted on the $30^{\text {th }}$ of December 2015, a special state program «Patriotic Education of Citizens of the Russian Federation on 2016-2020 years»);

- revival of sports and pre-conscription activities that includes delivery standards of "Ready for Labour and Defence";

- establishing exam on history as a compulsory part of the Unified State Exam;

- creation of a common set of national history textbooks, and, in the long term, in mathematics, the Russian language and literature;

- formation of Russian school movement;

- introduction of a single regional school uniform;

- performance of the national anthem at the celebration of the beginning of the school year;

- reappearance of the final essay at the end of school;

- consideration of socially significant indicators ("Ready for Labour and Defence" golden badge, participation in volunteer activities, tourist and local history work, etc.); high school graduate gets one additional point for the index, along with the results of the Unified State Exam when entering the university;

- use of the potential («all the best», according to the words of Vladimir Putin) Palaces of Pioneers, young technicians stations in the implementation of additional education;

- creation of educational complexes (kindergarten school) and so forth.

As it is clearly seen, such a direction of education policy, of course, implies a consistent and complete recovery of all the positive things that were in the Soviet system of education of the second half of the 1970 - early 1980 years, but they were successively excluded from the Russian education system in 1990 years.

As for some reason the combination of presented strategic provisions is not framed by any Russian Government nor the Ministry of Education and Science of the Russian Federation as a holistic document an urgent task of the Russian Academy of Education, and, especially, of the Institute for Strategy of Education Development of the Russian Academy of Education is to carry out a preliminary scientific justification of such a strategy, built on the national-patriotic and traditional conservative basis.

The elaboration of a new development strategy of the Russian education on the traditional-conservative basis in today's information society objectively requires the implementation of a historical and pedagogical expertise of the design process and implementation of such strategies of educational modernization.

It should be born in mind that in today's educational practices different types of innovations are implemented.
Along with projective innovations, now, more and more so-called retro innovations are exercised.

This capability is determined by a well-known frequency on a qualitatively new stage of development of the preceding events. In this regard, along with predictable forecasting, retro prediction acts as the base of prognostication. While reflecting «returning» historical phenomena (they practically return in its entirety) and associating them to the era from which they come, we can anticipate and, accordingly, comprehend from a scientific point of view the consistent inclusion of retro innovations into the new modern educational context. It must be emphasized that the concept «retro innovations» does not carry any negative connotations, but it only specifies this type of innovations, when previously presented phenomena «are returned» into modern education after a historic break [1].

For this purpose the historical and pedagogical expertise of the experience in the formation of practical implementation in the XIX - beginning of the XXI century of such a strategy of modernization of the Russian education is essentially important. This can contribute to the efficiency of joint efforts to develop and implement a new strategy of modernization of the Russian education, based on the priority of nationalpatriotic and conservative-traditional values in the domestic pedagogy.

In this regard, we need a complete recognition of both progressive and scientifically-pedagogical justification conservative dominant in the elaboration the strategy of the Russian education development. At present and for the future of the Russian state and society the conservatively-traditional basis for the development of the Russian civilization becomes the priority.

On this basis, a complex process of cultural and ideological transformation of the society and the formation of a new strategy for the development of the Russian society is developed. This new strategy provides a combination of its traditional strengths and at the same time ensures the import substitution, creation of competitive products in the modern world in the information society conditions.

In this context, strategic documents in the field of education should include a set of rules (guidelines, directions, areas, methods and rules), established for a sufficiently long period; these rules and guidelines are activities oriented on the achievement specified indicators that provide for the state and society the development of competitive education based on key traditional advantages of the domestic pedagogy. While maintaining the priority of universal criteria and objectives for future development the main emphasis should be put on the autochthonous form of their realization.

It should be taken into consideration that the most important in determining the strategy of modernization of Russian education is not in the structural and functional activities, development of packages of organizationalfinancial and program-methodical materials, but in determining the basic identification of values education, around which the main subjects of the educational process could unite. 
However, the fulfilled historical and pedagogical expertise of mutual co-existence of the mentioned strategies in the Russian education during the XIXbeginning of the XXI centuries, convincingly shows historical fatality repeatedly carried out acts directed to break an alternative strategy, acts taken one by one by either supporters of western-liberal trend or soilconservatives.

On the findings of historical and pedagogical analysis of current strategies of the Russian education modernization we can conclude that the «Strategy of strategies» appears to be harmonization of pedagogical grounds of objectively progressive western-liberal and traditionally-conservative development strategies of the Russian education in the following areas:

1. Emphasizing the priority of the Russian education national values it should not be isolated from the global processes of education; otherwise it will inevitably lead to its stagnation.

2. With the dominant of public socio-oriented values, person-oriented direction of the Russian education and its child-centered character must remain at the epicenter of attention.

3. With the growing trend towards the establishment of uniform textbooks in core subjects of general education, and activities to create a single state publishing house, engaged in the preparation and publication of textbooks, it is necessary to preserve and develop the variability and diversity of educational and methodical complex.

4. Having the dominant setting towards the cardinal revision of the general education standards, the introduction of standards in basic education content that really makes it possible to perform on a single contentbased Unified State Exams, it is strategically important to avoid retroversion of the education to purely knowledge paradigm; it is necessary to keep developing, personcentered ideology of Federal State Educational Standards.

5. Reflecting general fatigue of the pedagogical community because of innovations, striving for a moratorium on any conversion and the transition of the education system in the schedule of mastering innovations and the mode of operation, it is necessary to stimulate innovation activities of the content, rather than purely institutional nature.
The fact that all this can be realized in practice, convinces us that the highest state power is clearly trying at all levels, by recognition of the priority of traditional conservative values, to prevent the elimination from the political and socio-economic arena the spokesmen of western-liberal paradigm, and the system of values they advocate. In the projection for education it is evident in the preservation of western-liberal orientation of the higher education system and, to a large extent, in the scientific activity [4].

\section{References}

1. M.V. Boguslavskii, History of Pedagogy: methodology, theory, personalitie (Moscow, 2012) [In Rus]

2. M.V. Boguslavskii, Secondary education in Russia 3 (2014) [In Rus]

3. Official news portal, available online: URL http://www.kremlin.ru/events/president/news/51001 (Accessed 03.02.2016)

4. M.V. Boguslavskii, Values and meanings, 6 (40) (2015) [In Rus]

5. Critical analysis of bourgeois modernization theories: Coll. Reviews (Moscow, 1985) [In Rus]

6. A.S. Akhiezer, Russia: the critic of the historical experience (Novosibirsk, 1997) [In Rus]

7. V.V. Ilyin, A.S. Panarin, and A.S. Akhiezer, Reforms and counter-reforms in Russia: modernization cycles (Moscow, 1996) [In Rus]

8. A.N. Pozdnyakov, State and society in the reform of the Russian school education: historical experience of relations in the late XIX and early XXI centuries: thesis abstract of Doctor of Historical Sciences (Saratov, 2005) [In Rus]

9. I.D. Lelchitskii, The world of education - education in the world, 3 (55) (2014) [In Rus]

10. M.V. Boguslavskii, Proceedings of the Russian Academy of Education, 1 (29) (2014) [In Rus] 